\title{
Feasibility Study of Standalone PV-Wind-Diesel Energy Systems for Coastal Residential Application in Pekan, Pahang
}

\author{
Roziah Zailan ${ }^{1, *}$, Siti Nurzalikha Zaini ${ }^{2}$, Muhammad Ikram Mohd Rashid ${ }^{2}$, Amir Abdul \\ $\operatorname{Razak}^{1}$ \\ ${ }^{1}$ Faculty of Engineering Technology, Universiti Malaysia Pahang, Lebuhraya Tun Razak, 26300, \\ Kuantan Pahang. \\ ${ }^{2}$ Faculty of Electrical \& Electronics Engineering, Universiti Malaysia Pahang, 26600 Pekan, Pahang \\ Darul Makmur
}

\begin{abstract}
Techno economic study is feasible to optimize the usage of renewable energy components that targeting low cost of electricity generation system. The selected case study area is coastal area in Pekan, Pahang, Malaysia. The autonomous system designed in this study is hybrid standalone PV-wind-diesel energy system to fulfil a basic power demand of $20.1 \mathrm{kWh} /$ day. Such power system was designed and optimized further to meet the power demand at a minimum cost of energy using energy optimization software, Hybrid Optimization Model for Electric Renewables (HOMER). The analysis focused on the operational characteristics and economics. The standalone PV-wind-diesel energy system has total net present cost about $\$ 61,911$ with cost of energy $\$ 0.66 / \mathrm{kWh}$. Apparently, the generation of electricity from both wind turbine and PV can be inflated with the diesel generator. In comparison, return of investment (ROI) value turned out lower for Feed in Tariff (FIT) as compared to self-sustained house. Payback period also longer for FIT program that makes the selling back of electricity generated to Tenaga National Berhad (TNB) is considered not favourable.
\end{abstract}

\section{Introduction}

An abundant resources of solar and wind could be exploited to power up the coastal housing. However, the selection of location for suitable wind turbine and solar energy harvesting need to be studied in respect to the technology options, component costs, and resource availability. The study area located in Pekan, situated on the banks of Pahang River 50km South of Kuantan and near to popular beaches such as Legenda Beach and Air Leleh Beach. In this area, potential benefit to receive strongest wind and solar at coastal area will give advantages for this project. Therefore, this paper presents a feasibility study of hybrid standalone PV-

\footnotetext{
* Corresponding author: roziahz@ump.edu.my
} 
wind-diesel energy system for Pekan, Kuantan Pahang. The analysis was done based on typical house power demand at about $20.1 \mathrm{kWh} /$ day and $1.23 \mathrm{~kW}$ peak demand [1]. Noted that all cost conversion in this study is $1 \$=\mathrm{RM} 4.28$ as of current rate (August 2017).

Generally, total cost for establishing such generating unit in new location with unknown harvesting energy units is unclear without proper techno economic study. Therefore, this study is beneficial to optimize the usage of renewable energy components that targeting low cost of energy production. The arrangement of wind turbine, solar panel, diesel generator and storage systems were considered. Several configurations in the simulation include size of components, capacity, lifetime and so forth. The National Renewable Energy Laboratory's (NREL) optimization tool "HOMER" was utilized to identify feasible hybrid configurations and their applicability. HOMER simulates the operation of a system by making energy balance calculations and displaying a list of configurations, sorted by net cost that can be used to compare system design [1-4].

There are various previous studies using HOMER to initiate hybrid power system in the coastal areas. Sadrul Islam et al. [5] was attempted to model a hybrid electricity generation system for a small community of the St Martin's Island in Bangladesh that resulted lowest COE $\$ 0.345 / \mathrm{kWh}$ and total net present cost (NPC) of $\$ 137,927$ with a renewable fraction of $31 \%$. A study in the same study area by Hazra et al. [6] also stated that the depending on diesel only is not feasible but to integrate it with hybrid energy generation system. They concluded that PV-diesel-wind-battery hybrid generation system was found most feasible and optimized. Nevertheless, Ibrahim et al. [1] stressed that the hybrid renewable energy system is suitable to be applied in the coastal areas if current costs of the renewable energy components could be marked down.

In Malaysia, FIT is a policy mechanism which allows users to sell back the additional electricity generated from PV system to Tenaga National Berhad (TNB) based on TNB rate. This study also attempted to look into the possibility to participate in the FIT program. For this reason, the payback period ROI were calculated for both FIT program and self-sustained house to identify which one is more reliable to be applied. Matin et al. [7] also calculated payback period of the proposed system using different tariff based on their country, Bangladesh after they simulated hybrid PV-wind-diesel power system in HOMER to determine number of years required to recover the cost of investment. Therefore the economic analysis section will discuss more on the paybacks period and ROI analysis between self-sustained house and FIT program.

\section{Material and Methods}

\subsection{Energy demand and resources}

Electrical load: The electrical loads for the house are classified as domestic with basics electrical load components like fluorescent lamps, ceiling fan, television, refrigerator and also washing machine $[1,6]$. The hourly load consumed by the house is presented in Figure 1. Electricity demand is the rate at which electric energy is required by the load, measured in kilowatts $(\mathrm{kW})$ [8]. Average power demand was estimated at about $20.1 \mathrm{kWh} /$ day and peak demand of $1.23 \mathrm{~kW}$.

Solar radiation and Wind resources: Hourly solar radiation data and wind speed for year 2014 were collected from Malaysian Meteorological Department (MMD) as in Table 1. 
Table 1. Monthly Average Daily Radiation, Clearness Index \& Wind Speed

\begin{tabular}{|l|l|l|l|}
\hline Month & $\begin{array}{l}\text { Daily Radiation } \\
\left(\mathbf{k W h} / \mathbf{m}^{2} / \mathbf{d a y}\right)\end{array}$ & Clearness Index & Wind Speed $\mathbf{( m / s )}$ \\
\hline January & 4.2 & 0.44 & 2.37 \\
\hline February & 5.7 & 0.57 & 2.14 \\
\hline March & 6.3 & 0.61 & 2.12 \\
\hline April & 5.7 & 0.55 & 1.51 \\
\hline May & 5.7 & 0.56 & 1.56 \\
\hline June & 5.6 & 0.57 & 1.75 \\
\hline July & 5.2 & 0.52 & 1.8 \\
\hline August & 5.8 & 0.57 & 1.7 \\
\hline September & 5.5 & 0.53 & 1.57 \\
\hline October & 5.3 & 0.53 & 1.34 \\
\hline November & 4.2 & 0.44 & 1.36 \\
\hline December & 3.5 & 0.38 & 1.87 \\
\hline
\end{tabular}

PV-wind-diesel power system: The schematic diagram of Photovoltaic (PV)-winddiesel power system components are presented in Figure 1 consists of diesel generator, PV arrays, wind turbine, battery and power converters. Technical information to run the simulation using HOMER software were obtained from manufacturers of the equipment and previous studies [8-13].

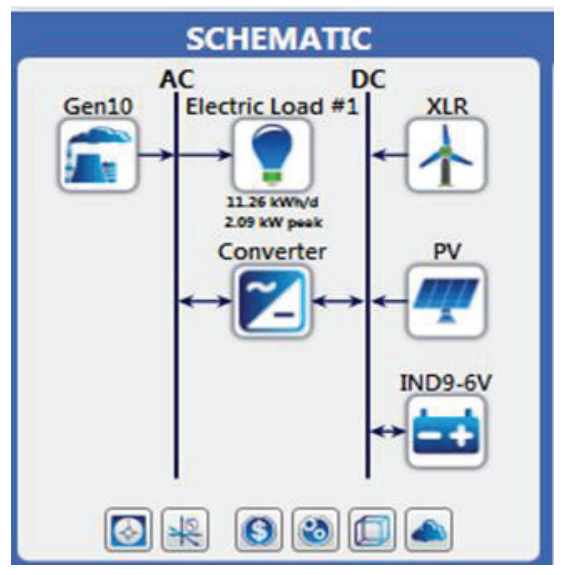

Fig 1. PV-Wind-Diesel Power System Configuration.

Table 2. Cost of Components.

\begin{tabular}{|l|l|l|l|l|}
\hline Equipment & $\begin{array}{l}\text { Capacity/ } \\
\text { Unit }\end{array}$ & $\begin{array}{l}\text { Capital } \\
\text { Cost (\$) }\end{array}$ & $\begin{array}{l}\text { Replacement } \\
\text { Cost (\$) }\end{array}$ & O\&M Cost (\$) \\
\hline Diesel Generator & $16 \mathrm{~kW}$ & 6500 & 5800 & $0.15 / \mathrm{h}$ \\
\hline Solar PV & $5 \mathrm{~kW}$ & 11000 & 9500 & - \\
\hline Wind Turbine & 1 Unit & 19400 & 15000 & $75 /$ year \\
\hline Batteries (Trojan IND9-6V) & 1 Unit & 1325 & 1190 & $0.02 / \mathrm{h}$ \\
\hline Converter & $1 \mathrm{~kW}$ & 118 & 100 & $15 /$ year \\
\hline
\end{tabular}




\section{Result And Discussion}

\subsection{PV-wind-diesel system simulation}

For hybrid PV-wind- diesel energy system, the equipment needed to build the system were diesel generator, PV array, wind turbine, batteries and power electronic converter with specified type and quantity. The HOMER simulation tool was used to optimize the sizes of different hardware components in the PV-wind-diesel system, taking into account the technical characteristics of system operation and minimizing total net present cost of the system. The optimization results of this power system are show in Figure 2.

\begin{tabular}{|c|c|c|c|c|c|c|c|c|c|c|c|c|c|c|c|c|}
\hline \multicolumn{12}{|c|}{ Architecture } & \multicolumn{4}{|c|}{ Cost } & \multirow{2}{*}{$\begin{array}{c}\text { System } \\
\text { Ren Frac } \\
(\%)\end{array}$} \\
\hline$\Delta$ & $m$ & t & E & $\Rightarrow$ & z. & $\begin{array}{c}\mathrm{PV} \\
(\mathrm{kW})\end{array}$ & XLR $\nabla$ & $\underset{(\mathrm{kW})}{\mathrm{DG}} \nabla$ & S6CS25P マ & $\begin{array}{c}\text { Converter } \nabla \\
(\mathrm{kW})\end{array}$ & Dispatch $\checkmark$ & ${ }_{(\$)}^{C O E} \nabla$ & ${ }_{(\$)}^{N P C} \nabla$ & $\begin{array}{c}\text { Operating } \\
\text { cost } \\
\text { (\$) }\end{array}$ & $\begin{array}{c}\text { Initial capital } \nabla \\
\text { (\$) }\end{array}$ & \\
\hline & & & E & th & z & & & 5.00 & 6 & 2.00 & $\mathrm{CC}$ & $\$ 0.584$ & $\$ 54,508$ & $\$ 3,585$ & $\$ 8,686$ & 0.0 \\
\hline & $m$ & & E & $t$ & z & 0.250 & & 5.00 & 6 & 2.00 & $\mathrm{CC}$ & $\$ 0.587$ & $\$ 54,800$ & $\$ 3,564$ & $\$ 9,236$ & 0.0 \\
\hline & & t & E & $t$ & z & & 1 & 5.00 & 6 & 5.00 & $C \mathrm{C}$ & $\$ 0.659$ & $\$ 61,496$ & $\$ 2,586$ & $\$ 28,440$ & 22 \\
\hline & $m$ & t & E & $\Rightarrow$ & Z & 0.250 & 1 & 5.00 & 6 & 5.00 & $C \mathrm{C}$ & $\$ 0.663$ & $\$ 61,911$ & $\$ 2,575$ & $\$ 28,990$ & 23 \\
\hline & & & in & & & & & 5.00 & & & $C \mathrm{C}$ & $\$ 0.787$ & $\$ 73,404$ & $\$ 5,703$ & $\$ 500.00$ & 0.0 \\
\hline & $m$ & & E & & Z & 0.250 & & 5.00 & & 2.00 & $\mathrm{CC}$ & $\$ 0.800$ & $\$ 74,660$ & $\$ 5,740$ & $\$ 1,286$ & 0.0 \\
\hline$\Delta$ & & t & $\bar{n}$ & & z & & 1 & 5.00 & & 2.00 & $\mathrm{CC}$ & $\$ 0.971$ & $\$ 90,571$ & $\$ 5,510$ & $\$ 20,136$ & 0.0 \\
\hline$\Delta$ & $m$ & t & E & & Z & 0.250 & 1 & 5.00 & & 2.00 & $C C$ & $\$ 0.975$ & $\$ 91,007$ & $\$ 5,501$ & $\$ 20,686$ & 0.0 \\
\hline & & t & & $\Rightarrow$ & z & & 24 & & 36 & 5.00 & $C C$ & $\$ 6.54$ & $\$ 609,997$ & $\$ 7,518$ & $\$ 513,890$ & 100 \\
\hline
\end{tabular}

Fig 2. The simulation results for PV-wind-diesel energy system

The least Cost of Energy (COE), $\$ 0.58 \mathrm{~kW} / \mathrm{h}$ resulted from the $5 \mathrm{~kW}$ diesel generator alone without contribution from renewable sources. But the integration with renewable energies fell into fourth least COE as $\$ 0.66 \mathrm{~kW} / \mathrm{h}$, resulted from the combination of $5 \mathrm{~kW}$ diesel generator, $0.25 \mathrm{~kW}$ of PV array, 1 unit of wind turbine, 6 unit of batteries and $5 \mathrm{~kW}$ converter. The strategy taken in this simulation is to ensure the power generator provide enough power to meet the demand. The renewable energy sources in collaboration with the diesel generator were evaluated to determine the feasibility of the system.

All values related to the electricity production and load served by the system are summarized in Table 3. The results of the simulation showed that the PV-wind-diesel hybrid system had a total annual electrical energy production of $10,046 \mathrm{kWh} / \mathrm{yr}$. The electricity generation came mostly from diesel generator with $56.32 \%$ at about $5,658 \mathrm{kWh} / \mathrm{yr}$ while wind turbine and PV-array generated energy at $42.82 \%(4,301 \mathrm{kWh} / \mathrm{yr})$ and $0.87 \%(87 \mathrm{kWh} / \mathrm{yr})$, respectively. Besides that, it is clear that approximately $8.7 \%$ of energy $(873.5 \mathrm{kWh} / \mathrm{yr})$ was neglected. Several amount of excess energy can be suggested to cater for PV-wind hydrogen energy system in the next study. The trend of monthly electricity production can be referred to Figure 3.

Table 3. Operational Characteristics of the PV-Wind-Diesel System

\begin{tabular}{|l|l|l|}
\hline Annual Electricity Production & $\mathbf{k W h} / \mathbf{y}$ ear & $\mathbf{\%}$ \\
\hline PV-array & 87 & 0.87 \\
\hline Diesel generator & 5,658 & 56.32 \\
\hline Wind Turbine & 4,301 & 42.82 \\
\hline Total production & $\mathbf{1 0 , 0 4 6}$ & $\mathbf{1 0 0 . 0 0}$ \\
\hline Annual electrical load served & & \\
\hline AC primary load served & 7,300 & 100 \\
\hline Total & 7,300 & 100 \\
\hline Other & & \\
\hline Excess electricity & 873.5 & 8.7 \\
\hline
\end{tabular}




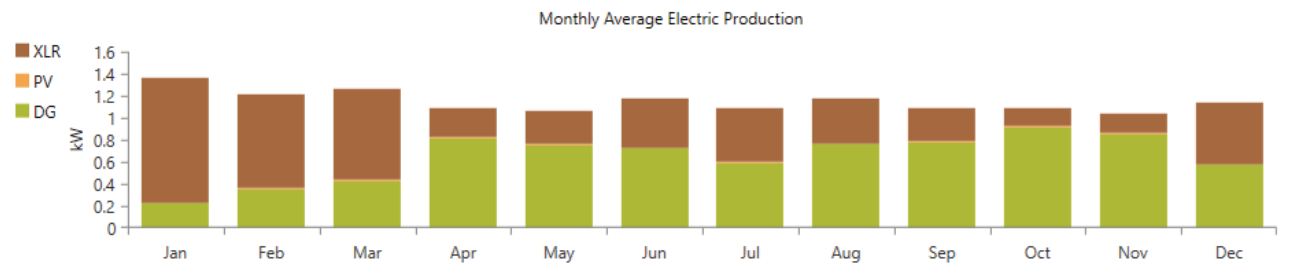

Fig 3. Monthly Electricity Production Trend of the PV-Wind-Diesel System

Through the economic analysis, the most expensive annualized cost is contributed from wind turbine at $\$ 1,518$ followed by batteries ( $\$ 622)$, converter $(\$ 46)$, PV (\$43) and diesel generator (\$39). Total annualized cost for overall system is $\$ 4,843$. HOMER uses the total net present cost (NPC) to represent the life-cycle cost of a system (Figure 8). The highest NPC came out from the BWC Excel-R wind turbine $\$ 19,400$, followed by batteries $\$ 7,950$, converter $\$ 590, \mathrm{PV}$ panel $\$ 550$ and diesel generator $\$ 500$. Total NPC is $\$ 61,911$. F

From this study, diesel generator apparently contributed highest portion of electricity while wind speed is highly potential in three months, January, February and March. The contribution from solar is very minimal. Apparently, fully dependent on the consumption of diesel fuel was reduced with integration of those renewable resources. All in all, capital cost, total Net Present Value (NPC) and COE of the systems were recorded as $\$ 28,990, \$ 61,911$ and $\$ 0.66 / \mathrm{kWh}$ respectively. From the analysis, COE is considered high until price reduction be made to respective devices involved in such system.

\subsection{Self-Sustained House and FIT Program Analysis}

On the other hands, economic analysis was done to complete this study by introduced other alternative in order to promote FIT that currently stirred by government through SEDA Malaysia. Therefore, both payback period and ROI were calculated to determine which one is favourable option between self-sustained house and FIT program. Table 4 provide detail summary of both option. Noted that the cost of electricity for installation above $4 \mathrm{~kW}$ and up to (and including) $24 \mathrm{~kW}$ is $\$ 2.90 / \mathrm{kWh}$ as of January 2017 [14]. Payback period was calculated to identify specific duration to recover the cost of investment of the system. Meanwhile, the return on investment (ROI) expresses the benefit to the investor resulting from an investment of some resources. A high ROI means the investment is worthy for the investment cost. As a performance measure, ROI used to evaluate the efficiency of an investment [15]. In comparison, ROI value for FIT program is lower as compared to the selfsustained house. Thus, the selling back of electricity generated to Tenaga National Berhad (TNB) is not recommended for the proposed system.

Table 4. Comparison between Self-Sustained House and FIT Program

\begin{tabular}{|c|c|}
\hline SELF-SUSTAINED HOUSE & FIT PROGRAM \\
\hline Total capital cost $=\$ 28,990$ & Total capital cost $=\$ 28,990$ \\
\hline $\begin{array}{l}\text { Annualize income }=\text { Total production } \mathrm{x} \\
\text { HOMER COE } \\
=10,046 \mathrm{kWh} / \mathrm{yr} \times \$ 0.66 / \mathrm{kWh} \\
=\$ 6894.4 / \mathrm{yr}\end{array}$ & $\begin{array}{l}\text { Annualize income }=\text { Total production } \times \mathrm{TNB} \\
\text { tariff rate }(\$) \\
=10,046 \mathrm{kWh} / \mathrm{yr} \times \$ 0.16 / \mathrm{kWh} \\
=\$ 1643.04 / \mathrm{yr}\end{array}$ \\
\hline Payback period $=4.2$ years & Payback period $=17.64$ years \\
\hline $\begin{array}{l}\text { ROI }=\text { Annualize income/ Total capital cost } \\
=\$ 6894.4 / \$ 28,990 \\
=0.24 \text { per annum }(24 \%)\end{array}$ & $\begin{array}{l}\text { ROI= Annualize income/ Total capital cost } \\
=\$ 1643.04 / \$ 28,990 \\
=0.06 \text { per annum }(6 \%)\end{array}$ \\
\hline
\end{tabular}




\section{Conclusion}

At the end of HOMER simulation, standalone PV-wind-diesel energy system presented total net present cost about $\$ 61,911$ that capable to generate electricity at cost of energy $\$ 0.66 / \mathrm{kWh}$. From the economic analysis, it has resulted that ROI for FIT program is lower than self-sustained house. Payback period also longer for FIT program that makes the selling back of electricity generated to Tenaga National Berhad (TNB) is not favourable. This study may be extended to involve the integration of other renewable resources system and environmental aspect for an extensive coastal area in the future.

\section{References}

1. M. Z. Ibrahim, R. Zailan, M. Ismail and A. M. Muzathik, Pre-Feasibility Study of Hybrid Hydrogen Based Energy Systems for Coastal Residential Application, Enrgy R. J 1, 1:1322 (2010)

2. Areef Kassam , HOMER Software Training Guide for Renewable Energy Base Station Design. (2010)

3. M. Shuhrawardy \& K.T Ahmmed, The Feasibility Study of a Grid Connected PV System to Meet the Power Demand in Bangladesh - A Case Study, American J. Enrgy Eng 2, 2 :59-64 (2014)

4. Z. Girma, Technical and Economic Assessment of solar PV/diesel Hybrid Power System for Rural School Electrification in Ethiopia, Int J. of Ren Enrgy R. 3, 3 : 735-744 (2013)

5. A. K. M. Sadrul Islam, M. M. Rahman, M. A. H Mondal and F. Alam, Hybrid energy system for St. Martin island, Bangladesh: An optimized model, Procedia Eng 49: 179188 (2012)

6. S. R Hazra, K. S. Hossain, A. Al Jubaer and M. Rabby, An Optimized Hybrid System Model : Solution for Coastal Area in Bangladesh, Int. J. of R. in Eng \& Tech 3,12: 94102 (2014)

7. M. A Matin, \& A. Deb, Optimum Planning of Hybrid Energy System using HOMER for Rural Electrification, Int J. of Comp App 66, 13: 45-52. 2013

8. Demiroren and U. Yilmaz, Analysis of change in electric energy cost with using renewable energy sources in Gokceada, Turkey: An island example. Ren \& Sust Enrgy 14: 323-333. 2014

9. M.J. Khan and M.T. Iqbal, Pre-feasibility Study of Stand-alone Hybrid Energy Systems for Applications in Newfoundland. Ren Enrgy 30: 835-854 (2005)

10. E.I. Zoulias and N. Lymberopoulos, Techno- Economic Analysis of the Integration of Hydrogen Energy Technologies in Renewable Energy-Based Stand Alone Power Systems. Ren. Enrgy 32: 680-696 (2007)

11. W.C Goh and N.N. Barsoum, Balancing Cost, Operation and Performance in Integrated Hydrogen Hybrid Energy System, http://www.itee.uq.edu.au/ aupec/aupec06/htdocs/ content/pdf/3.pdf (2006)

12. G.J. Dalton, D.A. Lockington and T.E. J. Baldock, Feasibility Analysis of Renewable Energy Supply Options for a Grid-Connected Large Hotel. Ren Enrgy 34: 955-964 (2009)

13. Bergey Wind Power. Small wind turbines: For homes, business and off-grid http://www.bergey.com (2017)

14. FIT Rates for Solar PV. http://seda.gov.my/ (2017)

15. K. Padmanathan, U. Govindarajan, V.K. Ramachandaramurthy, T.S.O. Selvi, Multiple Criteria Decision Making (MCDM) Based Economic Analysis of Solar PV System with Respect to Performance Investigation for Indian Market. Sust 9, 6: 820. (2017) 